For understottelse til denne afhandling bringer jeg *Den grevelige Hielmstierne-Rosencroneske Stiftelse* min bedste tak.

\title{
Kirkestuf og sakrale marknavne i Sønderjylland
}

\section{Af H. V. Gregersen}

Skønt tolkning af vore stednavne har været forsøgt i umindelige tider, hører den egentlige stednavneforskning dog til de unge videnskaber.') Først med oprettelsen af Stednavneudvalget i 1910 skabtes en ramme om et metodisk, videnskabeligt arbejde med det store navnestof, der rummes i vore stednavne.")

Et af de områder inden for denne videnskab, der gerne har pådraget sig størst opmærksomhed $\mathrm{i}$ offentligheden, vedrører de såkaldte sakrale stednavne, d. v. s. navnestof, der viser hen til gudedyrkelse fra førkristelig tid. Det hører derfor også til de emner, der får bølgerne til at gå højest de stednavnekyndige imellem. Man kan ligefrem opdele stednavneforskerne efter deres stilling til dette spørgsmål: $i$ en kreds, der forholder sig noget reserveret over for tolkningsforsøg i sakral retning, og en kreds, der med større dristighed mener at kunne finde spor af hedenskabets gudetro i vore stednavne. De sidste har utvivlsomt ofte skudt temmeligt langt over målet, men har på den anden side også haft en vis berettigelse ved at virke inciterende på forskningen.

Et ret omfattende navnestof af sakralt indhold lader sig imidlertid med sikkerhed påvise i vore bebyggelsesnavne, hvortil kildestoffet, hvad ælde angår, også i al almindelighed er bedst overleveret. De forskellige forekomster af denne navnetype har

1) En let læst oversigt og indførelse i emnet. har P. Skautrup givet i Sønderjydske årb $\varnothing$ ger 1937, s. $123 \mathrm{ff}$.

2) En populær oversigt over nyere dansk stednavneforskning findes i Nordisk Tidsskrift 1951, s. 102 ff. (Aage Houken). 
dog så ofte været behandlet - også for Sønderjyllands vedkommende ${ }^{3}$ - - at der ikke kan være grund til igen at komme ind herpå.

Et mægtigt navnestof - man anslår det for hele Danmarks vedkommende til mellem en halv og en hel million navne forefindes i vore marknavne, hvormed vi ikke blot forstår navne på jord under kultur, men også naturnavne på mindre lokaliteter sásom bakker og dale, skove og krat, kær og moser. Alene på grund af navnenes hyppige forekomst vil en omfattende undersøgelse af marknavnestoffet kunne få betydning for mange discipliner; således vilde blandt andet marknavnestof af sakralt indhold kunne øge vor højst sparsomme viden om den hedenske gudekultus.

Men spørgsmålet, der her straks melder sig til besvarelse, gælder da marknavnenes alder, idet vi kun har relativt få marknavne bevaret i middelalderlige kilder. lkke desmindre skulde der ikke være noget til hinder for, at adskillige af vore marknavne skulde kunne gå tilbage til $\mathrm{i}$ hvert fald vikingetiden og den tidlige middelalder. ${ }^{4}$ )

Med hensyn til overlevering af marknavnestof bør det dog i denne forbindelse noteres, at vore ældste marknavne som oftest skriver sig fra jord, der har tilhørt kirken (eller i modsat fald et stormandssæde), idet de netop hidrører fra opgørelser over den slags jord eller eventuelt fra stridigheder mellem gejstlige og verdslige stormænd. Indirekte har vi her et bevis på, at kirken nøje forstod at holde fast ved det een gang erhvervede, så at det ikke gik i glemmebogen.

Mange af de hidtil publicerede eksempler på kultminder $i$ marknavne må imidlertid siges at være af en noget tvivlsom karakter, idet de fleste marknavnes meget sene optegnelse gør det vanskeligt at fastslaa deres oprindelige indhold med sik-

3) Her kan foruden til »Sønderjyske Stednavne« henvises til de p pulære oversigter i S. årb. 1937, S. 122 (P. Skautrup), Nordisk Kultur XXV (Gunnar Knudsen) og Kr. Hald: Vore Stednavne.

4) Kr. Hald: Vore Marknavnes Alder (Namn och Bygd 1947, s. 1433), hvor middelalderlige marknavne fra L $\varnothing \mathrm{jt}$, Vedsted og Răhəde findes omtalt; se endvidere S. årb. 1951, s. $155 \mathrm{ff}$. med en fortegnelse over Bjolderup Kirkes jordtilliggende. 
kerhed. Dertil kommer, at den optegnede ældste skriftform i forbindelse med en moderne udtaleform i mange tilfælde slet ikke vil være nok til at fastslå et marknavns eventuelle sakrale karakter. Begge dele kan svigte. Der findes adskillige eksempler på endog meget stærkt forskrevne navneformer, ligesom en tilfældig udtaleoptegnelse for et marknavn, der måske kun er lrendt af ganske få stedkyndige personer, heller ikke bør tillægges alt for stor kildeværdi.

Der må noget mere til for at give et vist sandsynlighedsbevis, og vi har ment at finde en fremgangsmåde ved at undersoge, om der skulde være overensstemmelse mellem sakrale marknavne og det navnestof, der findes overleveret på kirkejord.

Denne undersøgelse beskæftiger sig kun med det område, der findes behandlet i. Stednavneudvalgets publikation „Sønderjyske Stednavne ${ }^{\text {c5 }}$ ), hvortil den derfor står i allerstørste gæld. Man finder her marknavnestoffet fra det hidtil største sammenhængende område i Danmark samlet; tilmed er foruden de fire sønderjyske amter også sognene omkring Ribe og de såkaldte otte sogne, der indtil 1864 hørte til det gamle hertugdømme Slesvig, taget med. Selvfølgelig har det ikke været muligt med denne publikation at få finkæmmet alt navnestof - man vil stadig i gamle dokumenter have held til at finde nye navne eller supplerende optegnelsesformer -, og det har heller ikke kunnet undgås, at der har indsneget sig åbenbare fejl..$^{6}$ ) Ikke desmindre vil dette værk dog langt ud i fremtiden være af fundamental betydning for enhver, der beskæftiger sig med Sønderjyllands stednavne.

Forinden det indsamlede navnestof på kirkejord fremlægges, er der grund til nærmere at berøre problemerne omkring det såkaldte kirkestuf i forbindelse med en vurdering af det overleverede kildemateriale.

Begrebet kirkestuf omtales første gang (og her tilmed kun en enkelt gang!) i Jyske Lov af $1241 .^{7}$ ) Det synes på daværende

5) I det følgendle citeret: S. St.

6) Af den fremkomne kritik kan næevnes S. årb. 1910, s. $11 \mathrm{ff}$. ( $\mathrm{H}$. Hiejselbjerg Paulsen) og Daniske folkemál 1943 (N. Black Hansen).

$\left.{ }^{7}\right)$ Det hedder her ( $\$$ I, 55): Gæær solskift a by. tha skal hwar man vp givæ siin hæfth om all mark vtæn thæt ær ornum oc kirki stuf. 
tidspunkt at have været en jordtype forskellig fra almindelig stufjord og med en lignende stilling som det såkaldte ornum, idet de begge lå udsondret af den øvrige byjord, ${ }^{8}$ ) men i modsætning til ornum, der som regel var et større sammenhængende jordareal, var kirkestuf kun en mindre „jordstump“; stuf afledes netop af „stub, stump“.

Men selv om Jyske Lovs bestemmelser ofte må antages at være en kodifikation af forlængst hævdvundne retsregler, bliver næste spørgsmål dog, om kirkestuf virkelig kan tænkes at hidrøre fra jordegods, der har været tillagt den hedenske gudsdyrkelse, og om der $i$ det hele taget har eksisteret jordegods af den art. Vi kan ikke give andet svar end det $i$ det følgende anførte navnestof, der al dets skrobelighed til trods dog i en række tilfælde synes at godtgøre denne antagelses rigtighed.

Når imidlertid de anførte eksempler er så vilkårligt fordelt ud over hele det sønderjyske område, skyldes dette givetvis udelukkende det foreliggende kildemateriale. Her bør, som nævnt ved omtalen af marknavnene i almindelighed, først og fremmest anføres det som oftest meget sene tidspunkt, da optegnelse har fundet sted. Almindeligvis hidrører de ældste oplysninger fra kirkeinventarier og udskiftningsakter fra årene efter midten af 1700-tallet. Kun fra få sogne findes kirkejord anført fra tidligere år, ældst er således listen over Bjolderup kirkes jordtilliggende fra $\left.1443 .^{9}\right)$ Det vil altså sige, at selv vore bedst afhjemlede marknavne ved en sakral tolkning må forudsættes at gå yderligere et halvt årtusind tilbage i tiden.

Det kan dog fastslås, at der, hvor man ved midten af $1700-$ tallet finder præcise udtalelser om kirkejorden, har man haft ældre optegnelser som forlæg. Ofte nøjes man imidlertid med blot at fastslå, at kirkejorden stammer fra så gammel tid, at man ikke mere er i stand til at bringe nærmere oplysninger herom. „En marck aff arrildtz tidt", hedder det således i Nørborg i 1589 .

Andet steds er kirkejorden i tidens løb blevet udlejet, såle-

8) Det ligger i selve navnet: or »ud af, uden for ‘, num af nemæ tager.

9) Trykt i S. årb. 1951, s. 155-159. 
des at dens eksistens kun kendes på grundlag af den årlige jordskyld, der svaredes af lejeren. I et sådant tilfælde er det selvfølgelig i nutiden ganske ugørligt at forsøge en stedfæstelse af den. „Kirken besidder dens Lænderier under det Navn af Kirkeland, men ved hvis Legatum er ganske ubekiendt, saasom dend har haft samme i utænkelige Aar; hvor samme Lænderier ligger, og hvor store de ere, er ikke til fulde bekiendt; af disse Lænderier tilhører Kirken en vis aarlig Afgift eller Canon, som kaldes Jordskyld“ (Vilstrup 1776).

For Sønderjyllands vedkommende er kildematerialet gennemgående dårligst fra Lundtoft herred og Sundeved. I egne, hvor som her patronatsretten til kirken ofte har været underlagt godserne, er der handlet ilde med kirkens ejendom. Også andre ting kan spille ind, $f$. eks. ødelæggelser af de stedlige arkiver ved præstegårdsbrande og lignende. Kildematerialet varierer derfor endog meget stærkt fra sogn til sogn. Helt galt er det således ofte med visse vestslesvigske sogne. Dette være sagt til forståelse af de anførte eksemplers ganske vilkårlige fordeling ud over landsdelen. Man kan derfor ikke udnytte materialet til en art "hedenskabets topografi"!

Men slet så galt er det nu heldigvis ikke gået alle vegne. Bedst finder vi som regel kirkejorden overleveret i de sogne, der lå under Slesvig bispestol, ligesom man fra Als almindeligvis også har udmærkede oversigter over, hvad der hørte til sognekirkerne. Der findes virkelig sogne, hvor kirkejorden har overlevet alle de storme, der har været siden reformationstiden, såsom krige, epidemier, ja selv udskiftningerne. Og forholdene i Bjolderup, Løjt, Uge og $\varnothing$. Logum viser, at selve reformationen ikke har berørt den jord, der lå til den enkeite sognekirke.

En anden ting er, at det, der senere hen kaldes kirkejord, ingenlunde behøver at være analogt med middelalderligt kirkestuf. Der er i tidens løb - og især i løbet af middelalderen stadig tillagt kirken jord ved donationer, og derfor vil der selvsagt eksistere megen kirkejord, der ikke har spor forbindelse med hedenskabets gamle gudetro. Langt de fleste navne på kirkejord adskiller sig da heller ikke på nogen måde fra andet navnestof. 
I den nedenstående oversigt over kirkejord bringes forst de navne, som formodes opkaldt efter hedenskabets gamle guder. Som det vil ses, er der kun overleveret relativt få eksempler, og af dem er endda en del tvivlsomme.

\section{Balder}

Boldeslund (Løjt s., Løjtkirkeby). S. St. anfører, at „Boldeslund ifølge den tyske matrikel støder op til Bundeslund (optegnet hos Johs. Mejer 1641) og må være fejl for dette". Boldeslund findes imidlertid $i$ samtlige kirkeinventarier og ligger ved Mørksø.

Boldershøj (Agerskov s., Agerskov) ligger mellem kirken og byen. S. St. lader det stå hen, om det indeholder gudenavnet eller et personnavn. Det forekommer første gang i en præsteindberetning fra 1766 og hidrører antagelig fra en senere tids trang til at navngive oldtidshøje.

Bolderstoft? (S. Starup s., Brorsbøl) ligger umiddelbart syd for jord, der er betegnet som „pastoratsland“. S. St. formoder, at det indeholder et mandsnavn svarende til oldtysk Baldheri eller gammeldansk Bolle. Endelsen -toft gør en sakral tolkning noget tvivlsom.

Bolderege? (Halk s., Sode), en egeskov, der ejes af kirkeinderster og ligger i Henneskær, der også findes optegnet som Hundskcer. S. St. formoder, at forleddet er et oprindeligt *bolager.

\section{Froy-Frøya}

Frøkcer (Bjært s., Agtrup) ligger på grænsen til Skartved. S. St.: "snarest af dyrenavnet frø". Da det drejer sig om gammel kirkejord, skulde der imidlertid ikke være noget til hinder for en tolkning med Frøy.

Frubyg (Bjolderup s., Bolderslev; Ødis s., Ødis ${ }^{10}$ ); Fjelstrup s., Sillerup). Efterleddet er her gammeldansk byggæ „,bygning“. Forleddet frue (her og de følgende eksempler) kan vel undertiden

10) S. St. I, s. 108: Bag fra By er fejllæsning for Back Fru By:, vden bageste del af Frubyg«. 
formodes at være en omtydning af Frerya, men den kan naturligvis også gå tilbage til tidligere Jomfru Maria-dyrkelse, kan have været ejet af en Vor Frue- eller Maria-kirke eller have tilhørt en adelsfrue. Endelsen -bygge synes dog at styrke en sakral tolkning. I denne forbindelse kan der anføres et stedligt sagn, knyttet til Fruens Pyt i Rolandsmose ( $\varnothing$. Løgum s.), hvor en frue ("Rolands enke“) skal være druknet sammen med hest og vogn. Et sagn af denne type peger uden tvivl tilbage til, hvad Tacitus meddeler $\mathbf{i}$ den så ofte citerede beretning om angleriolkets Nerthus-dyrkelse. Frudal (Fjelstrup s., Knud) mangler i S. St. ligesom Herre-Frudal, der også skrives Hørfrudall. Frudal ligger i Ildersig, Herre-Frudal i Lyngdeling (Fjelstrup kirkeinventarium 1763 og udskiftningsakter ca. 1770). I Broager s., Skelde, findes Horfrømose, om hvis evtl. kirkelige tilhørsforhold der intet kan siges på grund af kildematerialets svigten. Hørfrøløv (Øsby s., Årø) tolkes i S. St. af "*høffelløv „kristtorn" " og har ikke tilhørt kirken. I Angel (Hyrup s., Veseby) findes endelig et Herfrohäu, som med betænkelighed gengives i Sydslesvigs Stednavne ved "Hørfrøhave“. En mulighed skulde vel ikke være Frøyas tilnavn "Hærn, som man mener indgår i det svenske stednavn Härnevi, og som er formodet i det hjemlige Hindborg?

Fruegrav? (Svenstrup s., Svenstrup) er en mark umiddelbart nord for byen.

Fronstoft? (Moltrup s., Bramdrup). S. St.: „af frue“; ligger ved Griskær og Viehave.

\section{Njord}

Norager (Bjolderup s., Bolderslev) sammenblandes i S. St. med Nørreager, der er en helt anden lokalitet, jfr. Sønderjydsk månedsskrift 1951, s. 49-55, hvor det omtales i forbindelse med Frubyg; ligger i kratskoven Lyseg.

\section{Odin}

Vojenshøj (Ø. Løgum s., Ø. Løgum) ligger ved Hærvejen ca. $500 \mathrm{~m}$ syd for $\varnothing$. Løgum i nærheden af Tinghøj og Dværgehøj. 
Vonsmose (gård i Vilstrup) må oprindelig have været et marknavn og er vist nok identisk med Grimsti, der er·kirkejord. S. St.: „af gudenavnet Odin“. — Også Vonsbcek må i sin oprincielse have været et naturnavn.

Vonslyk, Vonstoft er andre navne på Okslykke (Egen s., Guderup), der også er gammel kirkejord.

Vongsbjerg? (Ris s., Søes og Hjordkær s., Årslev) findes oplegnet som både Vonsbjerg og Vunsbjerg. Omtydninger fra gudenavnet Odin til personnavnet Vogn bør her som andetsteds ikke lades upåagtet. ${ }^{11}$ )

\section{Ti}

Tisbjerg, Tiskcer (Egen S., Elstrup). S. St.: gudenavnet Ti, cldnordisk Tyr. Kendtest er forekomsten af dette forled i stednavnet Tislund.

\section{Tor}

Torshede (Hjerpsted s.) mangler i S. St., er kirkejord ligesom Tingdalhede.

Torshøj (Maugstrup s., Maugstrup) indeholder ifølge S. St. „vistnok gudenavnet Tor" og ligger nær ved Stævnhøj; kaldes 1564 Torsøø.

Torshøj (Hjordkær s.) ligger ved Stejlehøj og Kongstoft.

Torslund (N. Løgum s., Kløjeng) kaldes nutildags Torsland og indeholder ifølge S. St. "antageligt gudenavnet Tor".

Torsmose (Hagenbjerg s., Lavensby) må ifølge S. St. indeholde mandsnavnet Thord eller Thore!"

Torsmose (Egen s., Guderup), en mose ved Guderup by, tolkes ikke i S. St.

\section{Ull}

Dette gudenavns tilstedevær $\mathrm{i}$ vore marknavne må anses for yderst tvivlsom; det er tilmed nuomstunder ugørligt at skelne det fra dyrenavnet ulv. Ulbjerg (Nørborg s., Holm) og Ulhøj (Ketting s., Ketting) anføres derfor med alt forbehold.

1i) Jvf. Jahrbuch des Angler Heimatvereins 1954 s. 114 (Wolfgang Laur: Theofore Ortsnamen in der Landschaft Angeln, der imidlertid først forelå efter det herværende arbejdes tilblivelse). 
Som man vil se, er det alt i alt kun et fåtal af navne på kirkejord, der lader sig tolke af hedenske gudenavne. Hvor stor ælde, der kan tillægges disse, må imidlertid i mange tilfælde stả uafgjort hen.

Herefter skal der bringes nogle marknavne, som muligvis indeholder betegnelser på overnaturlige væsener og andre elementer, der kan tænkes at have spillet en rolle $i$ hedentroen, samt en del marknavne, der indeholder et dyrenavn, som kunde hentyde til tidligere tiders ofring.

\section{Gud}

Gudsbjerg (Åstrup s., Åstrup). S. St. har som opslagsform "?Guldsbjerg“, men de kirkelige dokumenter (og tilmed de ældste) har alle Gudsbjerg. Vi har altså her et eksempel på en omtydning fra Gud til guld.

Gudsbjerg (Taps s., Tapsore). S. St. oplyser her: „Gudsbjerg ligger ved Taps kirke og er vel gammel hedensk helligjord, hvorpå kirken er bygget". Det kan tilføjes, at der i kirkens våbenhus står en sten med soltegn, som tidligere lå foran indgangen.

Gudshøje (Egen s., Dyndved). S. St. mener her at måtte formode et oprindeligt *Guderupshøje, hvad der dog efter de ovenfor anførte eksempler ikke synes at være grund til at antage. Et eksempel på, at kendskab til, at det drejer sig om gammel kirkejord, kan have betydning for tolkningen!

\section{Hellig - Helvede}

Hellelund (Hørup s., Mintebjerg). S. St.: „af hellig“.

Heldbjerg eller Hellet (Aller s., Aller). S. St.: „snarest af helvede".

\section{Overnaturlige væsener}

Gyndbjerg (S. Bjært s., Agtrup), måske af jætte? Smlgn. jysk Jyndbjerg og Gyndovn (se kort i P. Skautrup: Det danske sprogs historie I, s. 74). 
Gymose (Åstrup s.), ellipse for *Gyndmose? Eller måske afledning af gyge "jættekvinde". Ifølge velvillig meddelelse fra Sv. Aakjær foreligger der muligvis et gammelt ord gug med ketydningen "grube, hulning, lavning“.

Lillemandsager (Ketting s., Ketting) ligger sammen med Lillehøj (et oprindeligt *Lillemandshøj?), også kirkejord.

Mandsager (Rabsted s., Foverup).

Mandhøj (Ullerup s., Avnbøl).

Karrlingholm (Bylderup s.) mangler i S. St.; kirkeinventarium ca. 1763: Kierlingholm. Måske hentydning til overnaturligt kvindeligt væsen (jf. Sydslesvigs Stednavne VII, s. 11; Kr. Hald).

Pugager (Hørup s., Hørup) indeholder ligesom nedenstående det sønderjyske "puge" for "nisse" $\mathrm{i}$ betydningen "ond ånd".

Pugbjerg (Hviding s., Høgsbro).

Pugholm (Højst s., Søvang).

Pughøj (Toftlund s., Rømet) lige vest for kirken.

Pugsø (Kegnæs s., Hjortholm), hvortil Galgeager støder op.

S. St. opfører i sit register henimod eet hundrede navne med ,trold“ som forled, men af alle disse ses kun Troldhøj (AllerTaps s.), Trolds Grue (Nybøl s.), Troldmark (Kegnæs s., Hjortholm) og Troldrøj (Ketting s.) at have været kirkejord. Overtroen har som bekendt helt op til vore dage arbejdet med trolde som et fast begreb, og der er derfor intet i vejen for, at dette ord endnu i vor tid kan have været produktivt ved stednavnedannelser.

Vittehøj (Højst s.) mangler i S. St., som dog til gengæld har gårdnavnet Vittegård, der tolkes på følgende måde: „muligvis gammeldansk wittæ "vætte“, snarest brugt som tilnavn“. I kirkeinventariet står imidlertid ved omtalen af Wittehoi: „der jetzige Besitzer ist Anthoni Marcussen in Wittegaard“. Gården har da sandsynligvis fået navn efter højen, hvis navn, eftersom det drejer sig om kirkejord, må anses for sakralt (med „der jetzige Besitzer" menes i kirkeinventariet lejeren af kirkejorden).

Barnhøj (Broager s., Mølmark; Asserballe s., Asserballe).

Barnsmose (Nørborg s., Holm). Lon det skulde dreje sig om 
særligt indviede steder, hvor børneudsættelser i gammel tid er foregået? Ofte er der til disse Barnhøje knyttet et sagn om barnet, der tages med ind $i$ højen af bjergfolkene.

\section{Lyset}

Solbjerg (Højst s.; Hørup s., Majbøl; Kegnæs s.). Soldyrkelse har været almindelig helt ned til vikingetiden, så Solbjerg kan udmærket være et vidnesbyrd om ældgammel soldyrkelse, se iøvrigt Vilh. Kiil i Mål og Minne 1936.

Tordenbjerg (Vedsted s., Ustrup).

Tordenhøj (Hagenbjerg s., Lavensby).

Tordenland? (Bjært s., Binderup). S. St. har opslagsformen ?Torland og formoder forleddet "torn". Tordenen som sakralt begreb var i særlig grad knyttet til dyrkelsen af Tor.

Bavne, blus og lys har helt op til nyeste tid været tændt ved visse folkelige højtider, og stednavne, hvori disse ord indgår, kan derfor referere sig hertil. Endelig kan navne på blus og lys hentyde til jord, givet til kirken med det formål at skaffe penge til kirkens vokslys. Skovnavne med forleddet lys- kan desuden være betegnelse på åben skovbevoksning. Navne med den slags forled er derfor meget tvivlsomme, men til trods herfor kan enkelte af dem udmærket have tilknytning til gammel lys- eller soltilbedelse, således Lysbjerg (Hammelev s., Hammelev), Lyseg (Bjolderup s., Bolderslev; jf. Norager), Lysholt $\varnothing$ dis s., Ødis), Lyshøj (Oksbøl s., Broballe; Lysabild s., Fjelby).

\section{Offerminder}

Brødbjerg (Varnæs s., Bovrup).

Guldbjerg (Hviding s., Råhede). S. St.: „Forleddet guld- kan sigte til bevoksning med gulblomstrede planter, eller et skattesagn kan have givet anledning til navnet". - Fund af guldsager findes også ofte nævnt som en mulighed i navne med guld- som forled.

Guldhøj (Tandslet s., Tandslet).

Guldkcer (Hostrup s., Hostrup).

Guldsten[s Esk] (Ketting s., Ketting). 
Guldtoft (Vonsild s., Vonsild).

Smørhul (Notmark s.) kendes nu kun som gårdnavn og skrives nuomstunder „Smørholm“. S. St. mener, at navnet stammer fra, at gårdien har leveret tiende til præsten i smør, og støtter sig herved til følgende citat fra stiftsbogen 1690: „Præsten af Nutmark har oc grund hass samme Boende, oc schall Boenden derfor gifve til hannem noget Smør om aaret. Derfor hedder det Smørhull, fordi Gaarden ligger i en hule, oc Boenden giffver Smør om aaret". Trods oplysningens ælde kan den dog kun have værdi som et forsøg på en navneforklaring.

Smorpyt (Asserballe s.) har vist forbindelse med ovenstående lokalitet.

Smørkilde[s ager] (Svenstrup s.).

Smorkar (Tandslet s.)

\section{Offerdyr?}

En del navne på kirkejord indeholder et dyrenavn som forled, af hvilke en del muligvis lader sig forstå som opkaldelse efter offerdyr. Langt de fleste må dog selv med bedste vilje anses for at være særdeles tvivlsomme, hvorfor kun nogle ganske få eksempler anføres her, og selv disse kun med den allerstørste betænkelighed.

Gåsbjerg (Nørborg s., Holm). Forleddet gås- står måske i nogle tilfælde som omtydning for Gud.

Hundborg (S. Stenderup s., S. Stenderup).

Hundsager (S. Stenderup s., S. Stenderup); uden topografisk forbindelse med ovenstående lokalitet.

Hundsbjerg (Ø. Løgum s., Hovslund).

Hønborg (Højst s.) findes omtalt i ,gamle breve ved pastoratet".

Hønborg (Løjt s., Løjtkirkeby) kaldes i 1609 „ein stück stuefflande".

Alhs (gotisk: „tempel“)?

Ålum (Bjolderup s. og Egen s., Guderup). S. St. tolker disse marknavne som et oprindeligt * $\AA$ holm. Alum i Bjolderup s. kan som kirkejord føres tilbage til 1443. Albjerg (Brede s.) og $\mathrm{Al}$ bjerg (Bjerning s.) synes derimod ikke at have været kirkejord. 


\section{Bygge („bygning“)}

Dette ord forekommer en del gange som endelse i navne på kirkejord. Ofte er det dog usikkert, om endelsen er -bygge eller -bøge ("bevoksning med bøgetræer"). De enkelte tilfælde er her anført efter forleddet (Frubyg, Staldbygge etc.).

\section{"Hargh („helligsted“)}

Hardal (Nustrup s., Kolsnap). S. St.: „af hare“.

Harmos (Løjt s., Løjtkirkeby). S. St.: „af hare eller *hargh". Harresholt (Hoptrup s., Mastrup), ca. 1763: Harritzholt; S. St.: „,Forleddet er måske genitiv af mandsnavnet Harald“.

Harreshøj (Tislund s., Tislund). S. St.: „Da stedet ligger lige syd for Tislund kirke og er samme lokalitet som S. Kirkeager, og da forleddet $\mathbf{i}$ Tislund er et hedensk gudenavn, kunde navnet sammenstilles med landsbynavnet Harres i Brede s., hvis forled er tolket af glda. "hargh "hedensk tempel, alter". En anden mulighed er mandsnavnet Harald, jfr. Harresbjerg i Tandslet" - I Sydslesvigs Stednavne formodes forleddet at være et usammensat stednavn ${ }^{*}$ Harre, identisk med "hargh.

Harsted (Åstrup s., Åstrup). S. St.: „formodentlig dyrenavnet hare".

Harsten (Asserballe s., Asserballe). S. St.: „dyrenavnet hare“.

Hørrild (Fjelstrup s., Sillerup). S. St. formoder, at forleddet skulde være en sideform *hørgh til *hargh og efterleddet -hillæ, som (af Sv. Aakjær) er blevet tolket med betydningen „tømmerbygning, gudehus af træ “ eller „tribune, forhøjning, hvorpå gudebillede er opstillet, og hvor gudsdyrkelse og trolddom øves" (smlgn. Harrild). Denne mark ses imidlertid ikke at have været kirkejord, men den ligger umiddelbart vest for kirkejorden i Frubyg.

\section{Hov}

Hovlund (Brede s., Vollum). S. St.: Da efterleddet er -lund, er forleddet snarere hov "hedensk tempel“ end hov $i$ betydningen "hoveri“".

Hovsvold (S. Stenderup), S. Stenderup). S. St. „Voldstedet Hovsvold, senere forvansket til Husvold, ligger på en lav holm. 
Forleddet er formodentlig et subst. glda. *hof med betydningen "forhøjning“, samme ord som norsk hov "lille høj". Mindre sandsynligt er det vel, at der foreligger (det muligvis etymologisk identiske) hov "gudehov"." Atter et eksempel på, at det kan have betydning for tolkningen at vide, at det drejer sig om kirkejord!

\section{Lund}

Lund (Løjt s., Løjtkirkeby). I indledningen oplyser S. St., at navnet kan gå tilbage til hedensk tid, eftersom et gudenavn indgår i Tislund, men formoder iøvrigt, at adskillige navne på -lund først er dannet $i$ løbet af middelalderen. Om karakteren af den her nævnte mark oplyser kirkeinventariet, at den ligger syd for præstegården „und gleich an dessen Hofraum und Garten anschliesst. Sie besteht sowohl aus Acker- als Wiesengrund, und enthält auch etwas Buschwerk zum Zäunen, nicht weniger auch einiger einzelne sowohl alte als junge Eichen von geringer Erheblichkeit. Sie ist ganz mit lebendigen Zäunen und gegen die Strasse zu noch überdem mit einem Steinwall versehen."

Lundager? Lundgab? Lundhøj? (Ketting s., Ketting). Man kommer her uvilkårligt til at tænke på Lundager præstegård ved Dronninglund (forhen Hundslund, jf. ovenfor).

Lunden? (Hørup s., Hørup).

Lunddal? (Oksbøl s.).

Lundsbjerg? (Brede s., Borg).

Lambjerg Lund? (Hørup s., Lambjerg).

Hraun (,røn“ o: stengrund)

Rønager? (Rabsted s., Korup). S. St. „trænavnet røn“.

Rønsager (Nybøl s.). S. St. henviser her til Rønsdam (Bov s., Bov), som tolkes „af plantenavnet eller det i flere jyske stednavne forekommende subst. røn "stengrund, sten"“.

Rønsdam (Sottrup s., Sottrup og Dybbøl s., Ragebøl). S. St.: „Forleddet er gen. af det røn, der indgår i sammensætningen Rønstam Røn, og som sikkert er identisk med oldnordisk hraun „stendynge, stengrund“". - Det kan tilføjes, at kirkeinventariet ca. 1763 har formen „Ravens oder Rønsdam“. 
Saks („sten“)

Saksager? (Hørup s., Hørup).

Saksbjerg (Notmark s., Hundslev).

Saksborg (Burkal s.).

Saksborg[lykke]? (Ullerup s.)

Sakslund (Ketting s., Ketting).

Stald (jf. Jerstal, Stollig etc.)

Staldbygge (Nørborg s., Holm). S. St.: „Staldbøge“, tolkes af "stold „forhøjning, offeralter".

\section{Sten}

Stenhøj (Hoptrup s., Hoptrup) er ikke en gravhøj.

Stenkammershøj? (Oksbøl s.), gravhøj?

Stenrøgel (Gram s., Gramby), ,hvorpaa der findes en stor breed Steen, noget nær 15 Alen omkring, paa huilcken, som der meenis, die haffuer offret i gamle Dage" (præsteindberetning i638).

\section{$\mathbf{V i}$}

Viedøbbel (Broager s., Broager). S. St.: „plantenavnet vie "vidje, pil“"“. - Ligger op imod kirken.

Viedøbbel (Løjt s., Løjtkirkeby). S. St.: „plantenavnet vidje“.

Kirkevi (Vilstrup s., Nr. Vilstrup). S. St. tolker dette navn af "vie, vidje“, da provstibogen har formen Kirkevier. - Kirkeinventariet ca. 1763 har navnet i singularis.

Kirkevi (Øsby s. Øsby). S. St.: „Et stort stykke agerjord umiddelbart ast for Øsby kirke nær ved Viager. Det er muligt, at efterleddet er subst. gammeldansk wi "helligdom, hvor der foregår ofringer", og at Øsby kirke er bygget på en gammel offerplads. Som en anden mulighed må dog nævnes det i sønderjyske stednavne hyppigt forekommende plantenavn vie „pil“, jfr. det tilstødende Kirkevie i Flovt, hvor udtalen med acc. 2 bedst lader sig forene med den sidstnævnte mulighed". - Mon det imidlertid lader sig gøre at tolke samme marknavn forskelligt, blot på grundlag af to forskelligt optegnede udtaleformer af måske ganske tilfældige meddelere? 
Uden tvivl tillader adskillige af de ovenanførte navne på gammel kirkejord ikke en sakral tolkning - selv med den bedste vilje. Alligevel vil fortegnelsen dog indeholde $i$ hvert fald et fåtal af marknavne, der uimodsigeligt synes at betegne gamle offerpladser, og alene dette berettiger til at hævde, at det faktisk lader sig gøre i nogle tilfælde at påvise en forbindelse mellem sakrale marknavne og gammelt kirkestuf - lige meget. hvor fătallige de enkelte eksempler end vil vise sig at være.

En nøje lokalisering af sådanne gamle offerpladser vil utvivlsomt være af en vis betydning for fremtidige arkæologiske undersøgelser, selv om vor viden om, hvad der er foregået under den hedenske gudedyrkelse i sig selv er så ringe, at man ikke bør gøre sig håb om sensationelle fund, tilmed da de vigtigste kultpladser i mange tilfælde utvivlsomt vil vise sig at være der, hvor vore kirker nu ligger. Kirkernes ofte noget umotiverede beliggenhed $i$ et sogn hidrører sikkert i mange tilfælde netop fra det hensyn, som vore første kirkebyggere har måttet. tage til sognefolkets vante forestilling om bygdens hellige sted. Få kirker i Sønderjylland har i den henseende en så slående beliggenhed som Vonsbæk kirke, der ligger „yderst på et lille plateau, hvorfra bratte, bugtede skrænter falder mod Odinsbækken og fjorden" (Danmarks Kirker, udg. af Nat. mus., Haderslev Amt, s. 501-502.

For studiet af den folkelige tradition $i$ al almindelighed har det sin store interesse at kunne påvise den ubrudte kontinuitet $i$ adskillige af vore marknavne helt op til vor tid, således at hedenske trosforestillinger endda på trods af et gennemgribende religionsskifte har kunnet holde sig i hvert fald i mere end tusind år. 


\section{Slesvigske Tilstande og Tanker omkring 1820}

(Udtog af Sognepræst Peder Kiers »Østerlygum Menigheds

Annaler« VI. Bd. 7 og 8. Bog.)

\section{Af H. Hejselbjerg Paulsen.}

Forfatteren er Pastor Kier i Østerløgum (1771-1834, Præst i Øster Løgum 1802-34), en Mand, som har skrevet meget baade om sin egen og den ældre Tid.")

Med Iver tog han sig af den jævne Mands Sag og søgte at tjene sit Sognefolk paa alle Maader. Sine Venner fandt han i det brede Lag. I og udenfor Sognet søgte man hans Raad og Bistand i alle Slags; Anliggender. Hans Ord og Raad blev fulgt, og han nod en urokket Tillid overalt.

Som det fremgaar af det følgende, havde Napoleon og alle Frihedsrørelser i Tiden hans varme Interesse og Beundring. Embedsstanden ventede han sig derimod ikke meget godt af. Selv levede han derfor ret isoleret og uden videre Omgang med sine ligestillede. "Medens mangen Medbroder i Embedet godter sig ved Selskaber og kostbare Adspredelser, finder jeg min Fornøjelse i, paa mit Studerekammer at gennemsøge gamle Skrifter og at skrive nyttige og behagelieTing ", skriver han i Indledningen til sit Ti-Binds Værk: "Østerlygum Menigheds Annaler", hvoraf her gengives nogle Udtog som formodentlig har Interesse for en videre Kreds.

\section{Juleaften 1814.}

"- - - Dette skriver jeg Juleaften, medens Degnen begrer til helligt. Ja Forløserens Fødselsdag ville vi holde. Men saasom Menneskene gjore nu, at de holder deres egne Fødsels-

*) Se nærmere »Søndierj. Maanedsskrift 1934 p. 114 ff., og Sǿnderj. Aarb. 1934 
dage højt, og selv Børns, ville vi ikke. Denne Siægts Egenkærlighed udtrykker sig deri. Den skal ej befordes hos os og af os. Men paa denne Aften, som siden paa Nytaarsaften samles alt Folket i Stuen. Vi æde og drikke og synge Jesum til \#re. Dette burde oftere ske i mit Hus.

Aftenen er skøn og rolig, jeg tænker paa min Menighed, mine Foresatte, mit Fædreland og min Konge. Gud give dem den søde Ro, som toner nu i mit Bryst, og den bedste Villie og Lydighed mod Dig og Haab paa Dig, Frederik; i Kejserstaden Wien dvæler $\mathrm{Du}$ nu i 3 Maaneder, vi vide slet ikke endnu, hvad Du udretter til Landets Vel, og om Du beholder Pommern og Rygen eller ej. Imidlertid regerer Din fromme Dronning i Ro. Men vi venter og haaber, at Du paa denne Rejse skal erfare, hvor lidet Landets Børn billiger Dine Omgivelser og ønsker, at de faar Afsked. Thi Pengenes Fald og Forandring, Krigens ulykkelige Udfald, Skatternes Formerelse, faar de Skyld for. Thi Norge er nu virkelig gaaet over til Forening med Sverrig. Handelen ligger stille, og Armod og Forlegenhed er stor.Skatterne for 1813 staar for de fleste her i Sognet ubetalte og altsaa for 1814 med. Imidlertid er vor Amtmand Otto Johann v. Stemann saaledes sindet, at han vil inddrive dem med Magt, cg han tænker kun lidet paa at skaane nogen. Skøn er Tilbøjeligheden til Kongehuset, og Troskab mod det, men den vorde aldrig til Tyranni og Haardhed mod Undersaatter. Mindre haard mod Bonden turde i saa Henseende Amtsforvalter, Kammerherre Samuel Hansen være. Men denne snilde, noget plumpe, ved forrige Levnet svækkede Mand er herskesyg, synes især vel om at byde over Gejstligheden. Let er det ogsaa til en Tid, da Regeringen holder den for temmelig overfledig og kan ikke lade den nogen Frihed. Eftertiden vil vise, at jeg ikke er partisk ..."

\section{April 1815.}

„Alle taler om Napoleon. Jeg tror og haaber, at han vil slaa de adsplittede Foreninger, og naar han vil slippe sin Erobrelyst; kan han vorde en ypperlig Kejser. Men hvad vil der blive af os? Vor Konge ligger endnu i Kongressen, uden at man aner det 
mindste om hans Forretning. Man siger at Carl Johann*) er ded, $\epsilon \mathrm{r}$ det sandt, saa vender Bladet sig, og vi kunne vel haabe at faa Norge tilbage."

„... en Kommission blev nedsat, hvad den udrettede vides ej; men at den gav sig af med at faa Hertugdømmerne adskilt tra Danmark og her en saakaldt Standsforfatning, for hvilken især de dannede Klasser og Øvrighedspersoner strede, er vist. I Holsten, som er et. tysk Land, opnaaedes Hensigten, og en Kommission arbejdede paa Indretningen. Men Slesvig vilde Kongen ikke lade fare. Og jeg ved heller ikke, hvad der kunde være vundet herved for Folket. Især daarligt synes mig det, naar man arbejder paa at beholde tysk her, da dog aabenbar Folkets Sprog er for det meste dansk."

\section{Juni 1819.}

"Aldrig har jeg i mine Dage saa inderlig onsket Regn, som jeg i disse Dage onsker den. Aldrig har jeg frygtet for Mangel som nu. Ak, Jorden er saa tør, i Dag den 4. Juni er der endnu intet Græs, Kreaturerne forsmægter af Tørst og Hunger. Dertil kom Nætterne mellem 28., 29. og 30. Maj med Nattefrost, saa at meget Korn, selv Rug, fordærvedes, som var ved at blomstre. Man skal i Bjolderup, Rapsted og andet Steds endog høste deraf. Eoghveden, som var kommen op, skal omsaas. Træernes Blade hænger som kogte. Idag var Nis Kromand fra Terkelsbøl her ag sagde, at i 6-7 Sogne er Rugen næsten ganske borte. Hvad skal der blive af os? Nye Konkurser i Mængde, og vi har allerede haft nok af dem. 4 Gaarde er bleven solgt, men alt gik til Omkostninger, og Kongen mistede 200 Rdlr. Restancer. Mon dette ikke skulde hjælpe til at oplyse Regeringen om Urimeligheden i Skattesætningen?"

\section{August 1819.}

»Jeg har i Dag en Art Fridag, da mine fleste Disciple er i Apenrade for at se den Fest, som holdtes i Gaar i Løjt, i Dag i Apenrade med at skyde en Træhjort, og i Morgen holdes med en Fart paa Vandet. Den driftige Snakmund Doktor og Physicus

*) Kongen i Sverrig. 
Neuber*) er Ophavsmand dertil, og det synes, at mange Folk er kommen. Regnen i Gaar har ikke afholdt dem, thi vi hørte i Aftes Kanonerne fra Løjt. Saaledes fordrive de store sig Tiden og fortære, mens Bonden, som skal betale, med Suk og Sorg høster den fordærvede Rughalm, som i mange Sogne ikke har mindste Kerne. Et saa ufrugtbart, tørt og usselt Aar kan jeg og ingen, som lever nu, huske. ... Jeg har skrevet en Klage for mit Sognefolk, hvad mon deraf vil følge? Tempora mutantur.

\section{Karensdag (25. Nov.) 1819.}

Vinteren begynder for Alvor. Skal Sneen nu ligge i 18 Uger efter de gamle Mærker? Kornet koster intet, og al Handiel ligger stille. Det ser saa uroligt ud, at jeg ingen Tillid har til nogen Ting. Fyrsterne trykker, Folket knurrer. Oprør ulmer i Tyskland, Frankrig, England. Her er det ondt, dog vel endnu bedst. Man troede, naar Bonaparte var faldet, saa var alt godt. Men desværre. Mange vilde være, hvad han troedes at være. Al Trykkefrihed er nu undertrykt og Censur indført, man siger, selv i Danmark. Dette kommer af Fyrsternes, især af den preussiske Konges, Frygt for de lærde og for deres Lærdomme. Rigtignok er de farlige for Fyrsterne og for deres Smigrere. Folket vil nyde den Frihed, som diet troer at have vovet Liv og Blod for, cg for hvilken det ser sig mere undertrykt. Hvad vil der ske? Tør Fyrsterne atter indføre de raa Tiders Forfatning, efter at der er arbejdet saa meget for Folkets Oplysning og givet det at kende sin Menneskeret? Det vil næppe gaa an. Ja, det er nok Formastelse. Men saa(ledes) er Menneskets Forfængelighed, ustadigt og ved ej, hvad det vil. For faa Aar siden hed det overalt: Lad Folket selv tænke. $\mathrm{Nu}$ derimod vil man ved at indføre den Lancasterske Metode*) gøre Børn til blotte Maskiner. Hvilke Forandringer. Soger den verdslige Magt nu ikke at øve samme Aandstyranni, som man har lastet saare hos den gejstlige i Tider, da den vel var nødvendig. Men det vil efter min Mening tage en anden Vending snart, og jeg er ikke glad ved Følgerne og vilde grulig frygte, hvis jeg ikke troede et Forsyn, som ej

*) En indvandret tysk Læge i Aabenraa. $\dagger 1849$.

*) En ny Undervisningsmetode. 
blot ser til. - - Det er nok endnu bedst i Danmark, endskønt det her er ondt. Vore Skatter er for store, og Handelen ligger stille. Vi plages af Jøder, derfor raabte man i København ved Dronningens Fødselsdag: Frederik leve! Bort med Jøderne!

Her i mit Sogn er kun lidet trøsteligt at se. Vor gode Amtmand vilde have lindret vore Smerter og andraget om, at vore Skatter dette Aar skulde skænkes, men det blev der intet af. Ak, Regeringen kan vel desværre ej undvære dem. For Resten er der stor Pengetrang hos os, og ingen kan betale. Jeg mærker det hver dag og ved alt, hvad der hændes. Saa lidt faar jeg derfor til Indkomst. Kun de, som ej tænker paa at nære sig, gifter sig, de andre vover det ej."

\section{Hosten 1820.}

„Hvor god end Høsten var, saa blev dog Bondens Kaar bedrøvelige. Thi der var og blev indtil denne Time ingen Pris paa Kornet og næppeAfsats. 4 Mk.-5 Mk. 5 Sk. var Rugprisen og 3 for Byg. Havren fra Als 2 Mk. 8 Sk. og ringe Havre endog kun 28 Sk. Tønden. Hornkvæget havde nogenlunde Pris, især Stude, men Hestene kostede elendigt lidt. For 17 Rdlr. fik man en dejlig Fole, som før kostede 50 Rdlr. Og under disse Omstændigheder krævede Amtmanden, at Bønderne endnu inden Mikkelsdag dette Aar skulde betale alle Restanter fra i Fjor, som blev staaende for Misvækstens Skyld. De skal altsaa betale, da de endnu intet har. $\mathrm{Ja}$, har mindre end i Fjor. Men saaledes tænker visse svage og sig meget indbildende Mennesker, fordi de har faaet en høj Post. Der pantedes ogsaa gyseligt, og kun faa betalte, thi de kunde ikke. Til Udvurdering skred man dog endnu ikke. Her i Sognet klagede man bitterligt, og dog høres, at mange $i$ de gode Egne er sunket langt dybere, fordi Overdaad havde tilforn sat dem i Gæld."

„.. . Det ser ud til, at nye Uroligheder vil udbryde i Europa, og hvo ved, om de ikke bliver værre end de forrige. Her i Fædrelandet er det endnu roligt, til paa nogle Optrin nær mod Jøderne, som her har altfor megen Frihed. Men hvor meget godt man haaber af den, som skal være Konge efter Frederik, 
dette kendes paa de Rygter, som udbredes, om hans Overdaad og* Vellyst, og hvad han koster Landet, da han rejser og lever $\mathbf{i}$ Neapel, dels af de Taler som for kort Tid siden udbredtes om en Kronprins, der skulde være bleven frelst fra Juliane Marias Morderstaal, opdragen hos en Præst i Sjælland eller Skaane og nu af Grev Thott bragt til vor Konge og antagen af ham. Man siger ogsaa, at det var en forfalden og halvforrykt Kadet, som havde indbildt sig at være Kongens Søn. Alle glædede sig over, at en Søn af Frederik skulde være funden. Jeg læste et Brev fra Laurits Matthiesens Kone i Kobenhavn, fuldt af denne Glæde, og her glædede man sig ogsaa derved, men nu synes alt at være forbi og glemt.“

\section{Nytaar 1821.}

"Saa har vi nu fuldendit dette Aar og med det femte Delen af det 19. Aarh. - Hvilken Forskel mellem Tilstanden nu og ved Aarhundredets Begyndelse. Og dette Aar synes at befæste den Trængsel, som nedtrykker, efterdi intet er ændret derudi. Aaret har været saare frugtbart og herligt, men hvad hjælper det den stakkels Landmand, som har dobbelte og mere Byrder imod dem, han havde ved Aarhundredets Begyndelse. Han kan kun faa Trediedelen af den Tids Priser for sine Varer. En Gaard; som da betalte 32 Rdlr. til alt, betaler nu 60-70. Men derfor er ogsaa Gaardens Værdli sunket saa dybt, at hvad dengang kostede 1200 Rdll., faas nu let for 200-300 Rdlr. Ogy det ser ud til at blive værre endnu, thi Regeringen - om den og vilde - kan ikke lette Folkets Fordringer. Men jeg vil se hen til mit Sogn, og her har jeg nogenlunde Trast deraf, at mit Sognefolk ikke just er ulykkeligt, da det har flere Slags Erhvervemaade. Hist i de vestlige Sogne, hvor alt skal komme ind ved Kornsalg, ser det værre ud.

Min Indkomst i Kirken ved 24 Lig, 30 Børn, 4 Trolovelser og \& Kopulationer var $456 \mathrm{Mk}$. og Offeret $248 \mathrm{Mk}$. Af min Tienderug, som var 209 Tønder, kan jeg sælge ca. 90 Tdr. Men da dienne Mængde ikke giver stort over $400 \mathrm{Mk}$., saa er jeg ikke vel deran, da jeg skal betale 4-500 Mk. i Pension, Renter og Skat. 
Jeg har 7-800 Mk. at leve af. Men jeg glæder mig dog ved dette Aar, da der var en Overflødighed af alle Kornsorter, og jeg behøver intet at købe. Saa maa jeg igennem, uagtet det er tungt, da Nutidens Byrder og Omkostninger er uforholdsmæssig store imod denne Tids Priser og Indkomster. Det er altsaa ligesaa let for mig at bestaa, som for andre, der have saa meget Korn, hvilket nu intet koster. Og Bønderne, især Kornegnene, er i største Forlegenhed. Er dette Følgerne af Freden, saa maatte vi igen onske Krig, men det er ikke Fredens Skyld, men Krigens Følgers Skyld, og Fyrsternes og Regeringernes Ødselhed og Ergerrighed. Byrderne i hele Europa er nu ogsaa saa haarde, at de ej kan bæres, og deraf følger den Tilbøjelighed til Oprør og Regeringsforandring, som allevegne i Europa viser sig og paa sine Steder bryder ud og bevirker heldige Forandringer. Der sker, hvad den forrige Hertug,*) en brav og kyndig Mand, og ej saaledes som den nuværende unge Jagtelsker, efter Provst Paulsens**) Fortælling for mere end 20 Aar forudsagde: Alting hælder til den constitutionelle Forfatning. Og det vil fremdeles ske, hvor meget end de mægtige Fyrster i Østerrig og Rusland modsætter sig.

Men hvorledes staar det her dermed? i det Land, hvor Kongen er født Enevoldskonge? Den danske Sindighed lader mig haabe, at alting kommer i Orden uden Voldsomhed. Regeringen vil engang erkende Nødvendigheden af at lette Byrderne og arbejde derpaa saaledes, at der sker efterhaanden og Uretfærdigheden forebygges. Thi uden dette vil det se ilde ud. Saa længe den danske Undersaat haaber at bestaa, taaler han, men stemmes Strængen for haardt, som jeg siger tit, saa springer den og kan springe Stemmeren i Øjet. - Hos os er der endnu ikke mange Konkurser, thi her har ikke været den Overdaadighed ej heller den Kreditgiven som i de gode Egne. Der er ogsaa Konkurserne skrækkelig mange, da Gaardene kun har Trediedelen af den forrige Værdi. Men bliver det saaledes ved, som det er nu, saa vil ingen kunne bestaa. Skatterne tager alt, Folk

*) Hertug Fnedierik Christian.

**) Prcvst Paulsen i Aabenraa (1811-37) havde fra 1807-11 været Slotspræst paa Graasten. 
ejer intet mer, har intet at miste og sætter intet paa Spil ved Opstand. Og hvad vil der saa ske? Gud skænke Regeringen Visdom og Kraft til at spare Folkets Formue og derved Rolighed. Jeg haaber dette gode og venter det. Jeg sammenligner ogsaa vor Tid med Tiden efter 1720. Den var ligesaa. Ingen Ting havde Værdi og sprang i Konkurs. Dog roses Datidens Konge, Frederik d. IV, fordi han fik Finanserne sat paa Fode igen. Men det glemmes, hvad Landet led, og dog saa han paa Sparsomhed, hvorpaa nu lidet ses. Frederik den VI synes at ville ophjælpe Kassen, men Sparsommeligheden savnes. Men hans gode Hjærte vil bløde og forandre, hvad muligt er, saa den flittige ikke skal miste sit sammen med den lade. I saadant Haab lever og taler jeg og opmuntrer Menigheden til Flid og Troskab og Sparsomhed og forsikrer, at disse Midler vil afvende alt ondt, som truer. Derfor taler jeg ogsaa paa Nytaarsdag 1821 over Sal. Ordspr. 10, 30 og Ps. 112, v. 6., og lærer, at den retfærdige skal bestaa uagtet alle Forandringer i Tiden. Og mange er disse. Jeg forundrer mig over dem, som er sket $i$ denne Femtedel af Aarhundredet. Dog, de vil gavne, naar man bruger dem med Visdom. De politiske Forandringer har vi set, Bonapartes Overmagt og Fald, og nu sidder han paa Sct. Helena. Vi har set Danmarks Tab, fordi man ventede Redelighed af Fyrsterne og bedrog sig. Men de vil falde som Napoleon, hvis de ej ændrer deres System. Og hvilket er det? Saa vidt jeg ser, at alting skal afhænge af de stores Naade, og Retfærdighed kendes ej. Derfor vil man ogsaa gerne befordre Misforstaaelser af Evangeliet, som jeg finder i det, at alt skal være Naade og Vilkaarlighed. Den pietistiske Lære rejser sig af den Aarsag mægtig igen, især, siden Napoleons Fald. Og det er en Forandring, som dette Viciennium har bragt med sig, hvilken jeg aldrig vilde have ventet. En Harms,") en Twesten, ${ }^{* *}$ ) en Kleuker, en Dieck her i Landet, en Marheineke og en Ammon i Tyskland, som for blot 20 Aar siden vilde være bleven latterlige, agtes nu højt især af de store, fordi de forfægte den dem saa kære Naadelære. Her i Sognet

*) Claus Harms i Kiel. T. og K. er Professorer i Kiel, som bekæmpede Rationalismen. 
ved jeg nu slet ingen, som holder sig til den. Men i Nabasognet Løjt er der mange, siden Pastor Matthiesen, uagtet han som Student syntes ene at være Filosof, er en sværmerisk Forfægter og Udbreder af denne Lære. Han er os ogsaa meget i Vejen i vore Konventer, som vi Præster holder her i Provstiet, og som skete anden Gang 5. Sept. i rode Kro. Her besluttede vi at befordre Bibellæsning i Skolerne og Bibelens Udbredelse. Og denne Beslutning er hos os ikke saa meget en Bekvemmelse efter Tidens Aand som en Følge af den Overbevisning, at Bibellæsning er højst nyttig. En anden Forhandling var om Sparekassers Oprettelse i Sognene ligesom i Apenrade. Denne Sag fandt egentlig ikke Bifald." 